\title{
Effect of Irrigation Scheduling on Economic Return of Onion
}

\author{
Pratibha Chauhan ${ }^{1}$, S.K. Srivastava ${ }^{1}$, Ir. D.M. Denis ${ }^{2}$, Vikram Singh $^{3}$ and D.V. Singh ${ }^{4 *}$ \\ ${ }^{1}$ Department of Irrigation and Drainage Engineering, Vaugh Institute of Agricultural Engineering \\ and Technology, SHUATS, Allahabad, India \\ ${ }^{2}$ Vaugh Institute of Agricultural Engineering and Technology, SHUATS, Allahabad, India \\ ${ }^{3}$ Dept. of Soil and Water Conservation Engineering SHUATS, Allahabad, India \\ ${ }^{4} \mathrm{KVK}$, Kandhamal, OUAT, Bhubaneswar, India \\ *Corresponding author
}

\section{A B S T R A C T}

Irrigation scheduling is a critical management input to ensure adequate soil moisture for optimum plant growth, yield, quantity, water use efficiency and economic return. Present

\section{Keyw ords}

Irrigation

scheduling,

Economic return,

Micro-sprinkler irrigation, $\mathrm{B}: \mathrm{C}$ ratio.

Article Info

Accepted:

31 July 2017

Available Online:

10 October 2017 study was conducted to find out the water use efficiency and economic return of onion at Sam Higginbottom University of Agriculture, Technology and Sciences, Allahabad. The study revealed that the total cost of production increased slightly with increase in irrigation levels due to insignificant increase in pumping cost induced by variation in seasonal water applied. The total cost of production in drip irrigation was considerably higher as compared with micro-sprinkler irrigation method mainly due to the variation in irrigation system cost caused by large number of dripper/ha and lateral length. The gross return increased sharply from 50 to $125 \%$ pan evaporation replenishment decreased the gross return due to decrease in crop yield. The net return increased sharply from 50 to $125 \%$ of pan evaporation replenishment due to sharp increase in crop yield. The benefit cost ratio of onion for all three irrigation methods increased considerably from 50 to $125 \%$ of pan evaporation replenishment due to sharp increase in gross return. The maximum benefit cost of onion for drip (16.31), for surface (13.86) and for micro-sprinkler (21.0) was obtained at $100 \%$ of pan evaporation replenishment. Surface irrigation give higher benefit cost ratio as compared with drip irrigation and micro irrigation mainly due to lower system cost.

\section{Introduction}

Water is the greatest resource to humanity. It not only helps in survival but also makes life comfortable and luxurious. Although water is renewable resource, its availability in appropriate quality and quantity is under severe stress due to increase demand from various sectors. Agriculture is the largest user or water, which consume more than $80 \%$ of the exploitable water resources.
The most plausible means of mitigating the scarcity of water in different regions of the world is through increasing the productivity of existing water resources and produce more food with less water.

Irrigation scheduling is a critical management input to ensure adequate soil moisture for optimum plant growth, yield, quantity, water 
use efficiency and economic return. Irrigation scheduling which determine the timing and amount of irrigation water is governed by many complex factors, but microclimate plays the most vital role.

Therefore it is important to develop irrigation scheduling techniques under prevailing climate conditions in order to utilize scare and expensive water resource efficiently and efficiently for crop production

In pressurised irrigation system water is conveyed through pipes under pressure and applied to the crops by drip and sprinkler over the land surface or plant canopy or applied on the soil surface as point source, usually in the form of drops.

Drip irrigation method offers the potential for efficient irrigation of valve crops and has proven feasible from engineering and agronomic stand points. Supply nutrient to the crop as needed and improve crop yield.

Drip, Surface and micro-sprinkler irrigation system with its ability to apply small but frequent water application have been found superior over other method in terms of water saving yield and irrigation production / water use efficiency (Theodore 1980; Pruitt et al., 1984; Srivastava et al., 1994; Hanson et al., 1997; Fekadu and Teshome, 1998).

At Coimbatore, India, Sivanappan et al., (1987) recommended drip irrigation system in place of conventional furrow irrigation due to economic water utilization to the extent of $84.7 \%$ without any loose of yield. Tiwari et al., (1998) reported $72 \%$ increase in okra yield under drip irrigation as compared to furrow irrigation.

Onions are widely grown across a range of climates but thrive best when temperatures are cool during early development and then warmer and sunny during maturity. They can survive at temperatures of $21^{\circ} \mathrm{F}$, but are killed when conditions drop below $18^{\circ} \mathrm{F}$. Optimum germination and emergence of onion seed occurs at temperatures of $55-83^{\circ} \mathrm{F}$. Higher temperatures favour accumulation of sulphur, pyruvate production and increased pungency.

Similarly, pungency increases in onions that suffer growing stresses. In temperate and warm temperate regions, depending on cultivar and environment, the crop cycle can take 9-10 months and the crops are either direct sown or transplanted in the autumn for harvesting the following spring or summer.

Thus, it is important to manipulate sowing density to provide maximum yields of a desired Planting crops at higher densities can increase light interception, but in thicker crops, bulb size.

Therefore the present study is undertaken with following objectives to cater the need of farmer in order to improve marketable yield, water use efficiency and economic return of onion to investigate the effect of irrigation scheduling on economic return of onion.

\section{Materials and Methods}

Field experiment was conduct to examine the influence of irrigation system and water management on response on onion. The necessary data regarding the crop, root yield, irrigation production efficiency and economic return of onion.

\section{Location}

Field experiment was conducted at the Irrigation Research Farm of Allahabad Sam Higginbottom University of Agriculture, Technology and Sciences, Allahabad during Nov 2016 to April 2017 


\section{Climate}

The climate in this part of country has been classified as semi-arid with cold winter and hot summer during crop growing period.

\section{Experimental layout}

The experiment was laid out in a two factor randomize block design with 3 replications the experiments comprise of 12 treatment with 4 irrigation level and 3 irrigation method. The area of each experimental plot was 3 square meter. The drip system was installed as per the layout.

\section{Treatment}

The experiment consists of 4 irrigation levels and three irrigation methods. The details of treatment are given below.

\section{Irrigation level}

$\mathrm{I}_{1}$ - irrigation at $50 \%$ of pan evaporation replenishment

$\mathrm{I}_{2}$ - irrigation at $75 \%$ of pan evaporation replenishment

$\mathrm{I}_{3}$ - irrigation at $100 \%$ of pan evaporation replenishment

$\mathrm{I}_{4}$ - irrigation at $125 \%$ of pan evaporation replenishment

\section{Irrigation methods}

D - Drip

S- Surface

M - Micro-sprinkler

\section{Economic analysis}

In order to assess the economic viability of drip, surface and micro sprinkler irrigation system, both fixed and operating cost was included. Total cost of production, gross return net return, and benefit cost ratio under variable irrigation was estimated on following assumption;

The fixed cost including water development (tube- well, motor, pump, pump house, water storage tank and other accessories), irrigation (PVC and LDPF pipe for main, sub main and laterals, filter, fertilizer unit, pressure gauge, control valve, water meter, dripper, micro sprinkler and other accessories) and spraying and weeding equipments for different irrigation methods and schedules were calculated by following approach (James and Lee, 1971).

The total cost of production, gross return and net return under different irrigation level were estimated under following assumptions:

Salvage $=0$

Useful life of pump, motor and pump house $=$ 25 Year

Useful life of water storage tank $=12$ Year

Useful life of drip irrigation system $=8$ Year

Useful life of micro sprinkler irrigation system $=8$ Year

Useful life of weeding and spraying equipment $=7$ Year

Interest rate $=13.75 \%$

Repair and maintenance $=2.5 \%$ of fixed cost

Number of crops per year $=2$

Capital Recovery factor $=\mathrm{i}(1+\mathrm{i}) /(1+\mathrm{i})^{\wedge} \mathrm{n}-1$

Where,

$\mathrm{I}=$ Interest Rate, fraction

$\mathrm{n}=$ useful life of the component, year

Annual fixed cost $/ \mathrm{ha}=\mathrm{CRF} \times$ fixed cost $/$ ha 
Annual fixed cost $/$ ha $/$ season $=($ annual fixed cost/ha) / 2

The operating cost including labour (system installation, irrigation, planting, weeding, cultivation, fertilizer, and chemical application, harvesting, packing etc) land preparation, land rate, seed, fertilizers, chemical, water pumping and repair and maintenance (tub-well, pump, electric motor, pump house, water tank, irrigation system etc) were estimated. The gross return was calculated taking into consideration the yield and current wholesale price of onion. Subsequently, the net return for onion was calculated considering total cost of production and gross return.

Total cost of production $=$ fixed cost + operating cost

Gross return $(\mathrm{c} / \mathrm{ha})=$ Marketable yield $(\mathrm{t} / \mathrm{ha}) *$ wholesale price $(/ \mathrm{t})$

Net Return ( $/$ ha $)=$ Gross return $($ ' $/$ ha $)-$ Total cost of production ( $/$ ha)

The benefit cost ratio $(\mathrm{B} / \mathrm{C})$ was calculated as follows;

Benefit cost ratio $=$ Gross return ( $/$ ha) $/$ Total cost of production ( $/ \mathrm{ha})$

\section{Result and Discussion}

The total cost of production, gross return, net return and benefit cost ratio of onion in relation to irrigation methods and irrigation schedules are presented in Table 1. The total cost of production increased slightly with increase in irrigation levels due to insignificant increase in pumping cost induced by variation in seasonal water applied. The cost production for drip and micro-sprinkler irrigation methods varied from 113009.31to 123933.9 and 83425.4 to 94350.1 / ha respectively. The total cost of production in drip irrigation was considerably higher as compared with micro-sprinkler irrigation method mainly due to the variation in irrigation system cost caused by large number of dripper/ha and lateral length. The gross return of onion under different irrigation level of drip and micro-sprinkler irrigation methods ranged from 342500 to 712500 and 285000 to 712500 / ha respectively. The gross return increased sharply from 50 to $125 \%$ pan evaporation replenishment decreased the gross return due to decrease in crop yield. Drip and micro-sprinkler irrigation methods resulted in almost same gross return.

The net return of onion under different irrigation level for drip, surface and microsprinkler irrigation methods ranged from 1152837.4 to $1594707.4,455502.36$ to 844639.03 and 1052221.41 to $1548348.11 \%$ ha. The net return increased sharply from 50 to $125 \%$ of pan evaporation replenishment due to sharp increase in crop yield. A further increase in the irrigation level from $100 \%$ of pan evaporation replenishment reduced the net return. The maximum return of drip (1590707.4\%ha), surface $(844639.03 \%$ ha) and micro-sprinkler $(1548348.11 \%$ ha) were obtained when irrigation during the crop-growing season was applied at $100 \%$ of pan evaporation replenishment. Surface Irrigation gave the highest net return as compared to drip and Micro irrigation methods, mainly due to the lower system cost. In spite of low microsprinkler and Drip irrigation mainly due to lower gross return (Table 1).

The benefit cost ratio $(\mathrm{B} / \mathrm{C})$ under different irrigation level for drip, surface and microsprinkler irrigation methods ranged from 11.91 to $16.31,8.30$ to 13.86 and 14.59 to 21.00 respectively. 
Int.J.Curr.Microbiol.App.Sci (2017) 6(11): 5454-5459

Table.1 Economic return of onion under different irrigation schedules and irrigation methods

\begin{tabular}{|c|c|c|c|c|c|c|c|c|c|c|c|c|}
\hline \multirow{2}{*}{$\begin{array}{c}\text { Treatment } \\
\text { (Pan } \\
\text { evaporation } \\
\text { replenishment, } \\
(\%)\end{array}$} & \multicolumn{3}{|c|}{$\begin{array}{c}\text { Total cost of production } \\
\text { ( } / / \text { ha) }\end{array}$} & \multicolumn{3}{|c|}{$\begin{array}{l}\text { Gross return } \\
\text { (//ha) }\end{array}$} & \multicolumn{3}{|c|}{$\begin{array}{l}\text { Net return } \\
\quad \text { ('/ha) }\end{array}$} & \multicolumn{3}{|c|}{ Benefit cost ratio } \\
\hline & Drip & Sprinkler & Surface & Drip & Sprinkler & surface & Drip & Sprinkler & surface & Drip & sprinkler & surface \\
\hline 50 & 101152.6 & 75911.89 & 57954.3 & 1499733.33 & 1129133.33 & 491780 & 1398580.73 & 1052221.41 & 635845.70 & 14.82 & 14.86 & 9.96 \\
\hline 75 & 102622.6 & 77381.89 & 9424.3 & 1653800 & 1521400 & 705133.33 & 1557177.4 & 1445488.11 & 695709.03 & 16.16 & 20.03 & 12.81 \\
\hline 100 & 104092.6 & 77381.89 & 60894.3 & 1698800 & 1625733.33 & 905533.33 & 1594707.4 & 1548348.11 & 844639.03 & 16.31 & 21.00 & 13.86 \\
\hline 125 & 105562.6 & 78851.89 & 62364.3 & 1258400 & 1151533.33 & 517866.66 & 1152837.4 & 1072681.44 & 455502.36 & 11.91 & 14.59 & 8.3 \\
\hline
\end{tabular}


The benefit cost ratio of onion for all three irrigation methods increased considerably from 50 to $125 \%$ of pan evaporation replenishment due to sharp increase in gross return. A further increase in pan evaporation replenishment decreased the benefit cost ratio. The maximum benefit cost of onion for drip (16.31), for surface (13.86) and for microsprinkler (21.0) was obtained at $100 \%$ of pan evaporation replenishment. Surface irrigation give higher benefit cost ratio as compared with drip irrigation and micro irrigation mainly due to lower system cost (Table 1).

The overall result shows that irrigation at $100 \%$ of pan evaporation replenishment resulted in higher gross return and benefit cost ratio. The result further revealed that Surface irrigation system resulted in higher gross return, net return and benefit cost ratio. Drip irrigation methods resulted in higher crop yield and irrigation production efficiency followed by micro-sprinkler methods and surface irrigation shows the highest benefit cost ratio. Though drip irrigation methods are costly but the result clearly depicts high profit resulted from high production and efficiency.

\section{References}

Aklilu, S., 1997. Onion research and production in Ethiopia. Acta Horticulture, 433:95-97.
Al-Jamal, M.S., Sammis TW, Ball S, Amel D.2000. Computing the crop water production function for onion. Agriculture Water Management, 46(3):253-266.

Annandale, J.G., Stirzaker, R. J., Singels, A.; Laan, M. van der; Laker, M. C. Irrigation scheduling research: South African experiences and future prospects. (Special Issue: WRC 40-year celebration special edition 2011.) Water SA; 2011. 37(5): 751-764.

Bangali, A.N., 2012. Effect of scheduling of drip irrigation on growth, Yield and water use efficiency of onion (Allium Cepa) Indian Karnataka, Journal of Agriculture Science, 25(1): 116-119.

Mermoud, A., Tamini TD, Yacouba H. 2005. Impacts of different irrigation schedules on the water balance components of an onion crop in a semi-arid zone. Agricultural water management, 77:282-295.

Montoro, A., Lopez-Fuster, P., Fereres, E. Improving on-farm water management through an irrigation scheduling service Irrigation Science; 2011. 29(4): 311319. 40

Ojala, J., C. Stark, and G.E. Kleinkopf. 1990. Influencing on onion crop (Allium cepa) cultivated under controlled deficit irrigation conditions in a semi-arid climate.

\section{How to cite this article:}

Pratibha Chauhan, S.K. Srivastava, Ir. D.M. Denis, Vikram Singh and Singh, D.V. 2017. Effect of Irrigation Scheduling on Economic Return of Onion. Int.J.Curr.Microbiol.App.Sci. 6(11): 5454-5459. doi: https://doi.org/10.20546/ijcmas.2017.611.522 